\title{
From Clay Feet to New Psychology: Starting the Move
}

\section{Jaan Valsiner ${ }^{1}$}

Published online: 25 June 2020

(C) Springer Science+Business Media, LLC, part of Springer Nature 2020

\begin{abstract}
This Special Issue sets the stage for constructive integration of psychology with relevant phenomena it needs to study, and with its interdisciplinary collaboration possibilities. Based on a regular submission of an analysis of the conceptual network of psychology (Zagaria et al. 2020) an international constructive discussion ensued, with charting out three potential future pathways to psychology as science: (1) theoretical elaboration of the person-centered and idiographic approaches and move from "evidence-based" to experience-based research; (2) advancement of general developmental science perspective beyond the traditions of evolutionary psychology along the lines of the genetic logic of James Mark Baldwin, and (3) building interdisciplinary synthesis between psychology and semiotics in the domain of cultural psychology. The progress in contemporary biology (epigenetics) and qualitative mathematics can provide the epistemological support for this move.
\end{abstract}

Keywords Crisis · Concepts · Epistemology · Evolution · Development - Semiotics · Person-centered focus $\cdot$ Experience-based research $\cdot$ Genetic logic

Psychologists like to feel hey are not treated as equals among other scientists. This may be true - if we look at the ever-repeated laments about "we are in crisis" and the normative insistence of quantification as the guarantor for being "scientific". Compensatory efforts for inferiority become defensive fortifications that make interdisciplinary syntheses complicated. I must admit I have over years as an editor of two journals and a number of academic book series become bored by the ongoing clever but unproductive discussions of the various versions of crises. I want to scream-if we are in crisis, please work our way out of it! My silent screaming is not likely to be heard.

However, when the regular submission to IPBS under the poetic title-Psychology: A giant with feet of clay (Zagaria et al. 2020) reached my Chief Editor's desk I was pleasantly surprised. The young Italian researchers had undertaken a project to analyze

Jaan Valsiner

jvalsiner@valsiner.org

1 Aalborg University, Denmark and Sigmund Freud Privatuniversität, Aalborg, Austria 
psychology's conceptual basis, locate exiting gaps and contradictions in it, and offer a way out. Despite disagreeing with their suggested solution - to turn psychology into evolutionary psychology - I felt that here is a starting point for a constructive international dialogue with open ended study of potentials for psychology's future. I invited colleagues from all over the World to contribute - and most of them were not only enthusiastic but also quick. The result is the present Special Issue-with contributions from 13 countries from Asia, Europe, and the Americas (Serbia, Denmark, Italy. Georgia, Macau, Spain, Sweden, Norway, Estonia, Poland, Russia, Brazil, and China). Reading through all the contributions I was deeply intellectually pleased about the constructive nature of the collective effort. The reader of this Special Issue is up to an intellectual gourmet dinner of sophisticated ideas and new directions.

How do we get from deconstruction to reconstruction? While agreeing with the evaluation of the current state of affairs as less than complimentary (Toomela 2020; Toomela and Valsiner 2010; Mazur 2020; Märtsin 2020; Mironenko and Sorokin 2020), the different possible directions presented in this Issue open very promising opportunities that preserve the past but make it possible to construct the future. The enthusiastic plea by Zagaria et al. (2020) for the future of evolutionary psychology as the via regia for the future is met with healthy doubt by a number of the contributors. Or better- the focus on evolutionary ideas brings to our attention the opportunity to continue the work of James Mark Baldwin of a century ago in the construction of developmental logic (Marsico and Calandrini 2020; Marti 2020) which would make the tradition of Developmental Science introduced in the 1990s at the Carolina Consortium of Human Development (Cairns et al. 1996) constructive -beyond the popular nice name that continues to circulate in psychology in the twenty-first century. The epistemological possibility to focus on human being in movement (Brinkmann 2020) is a crucial basis for new efforts towards a new evolutionary psychology on the basis of Baldwin's theory of organic evolution and without the confines borrowed from the Darwinian version (Baucal and Krstic 2020; Valsiner 2010). This direction is supported by the advancements in contemporary genetics where the Epigenetic Revolution since the 1970s has created a science by far more advanced than our current evolutionary psychology (Lux and Richter 2014). Bringing qualitative mathematics (Rudolph 2013; Tsuda 2001; Varzi 1998) together with the eco-systemic developmental and cultural perspective (Tateo 2020) should allow for substantive evolution of psychology as a science of the open systemic nature of the psychological functions (Gamsakhurdia 2020, Valsiner 2017). The unity of the abstract model and concrete human action is where psychology could reinstate itself ( Wu and $\mathrm{Xu} 2020$ ).

Would such new developmental science of psychology fulfill the hopes of researchers who desperately need to make psychological research person-centered (Lundh 2020)? It looks like the epigenetic epistemology of systemic flexibility of organisms maps precisely on the uniqueness of persons and psychological phenomena. What is needed is experience-based (Baumann 2010) rather than evidence-based science-which is brought into psychology of the twenty-first century by the move to idiographic science (Molenaar 2004, Salvatore et al. 2009, Salvatore et al. 2010a, $2010 \mathrm{~b}$ ) and thanks to the individual-historical invitation to research (Valsiner and Sato 2006) within the Trajectory Equifinality Approach (Sato et al. 2016), It is the individual unity of psychological functions that forms the basis for psychology as science, rather than collected bits and pieces of reported opinions that are accumulated over a sample 
and presented as if these pertain to the individual - even if abstracted generic- person (Valsiner 1986). The future of psychology in the realm of person focus emerges at the intersection of developmental and clinical perspectives (Lundh 2020). It is the phenomenological immediacy (Jensen 2020) that can be taken to the domain of technological innovations (e.g, robotics- Di Nuovo 2020) that force the new versions of psychology to be practice-linked and ready for innovations which are always acted out on particular cases.

The recent history of psychology that could be characterized by the label postcognitive has led to interesting bifurcation in directions. On the one hand we can observe the powerful avalanche by the neurosciences that eradicate the higher psychological functions from the coverage of psychology and reduce psychological functions to the functioning of brain structures. This tradition in science is old-we can see efforts to reduce organic chemistry to anorganic chemistry, chemistry to physics, bilology to chemistry, and so on. All these reductionist efforts have failed-yet creating hybrid disciplines on the border of areas (physical chemistry, biochemistry).

On the other hand we can observe in recent decades the effort to study higher psychological functions at the intersection of psychology with semiotics - the study of signs. The result - cultural psychology - provides a number of possibilities that are covered in the present Special Issue (DeLuca Picione 2020, Gozli 2020, Märtsin 2020, Pinheiro 2020, Tateo 2020). "Culture" is of course a complicated concept that leads to many interpretations that create a need to distinguish the value of inter-individual (cross-cultural- Christensen 2020) and individual-socioecological reference frame (Valsiner 2017). Cultural psychology has proceeded on a complicated path since its emergence in the 1990s (Valsiner 2019) yet its potentials are still very minimally realized in those fields - clinical, organizational, and economic.-psychologies.

\section{Conclusions: Pathways to Innovation}

We find three potential future pathways to psychology as science as different authors suggest in this Special Issue. They are mutually compatible-yet stand out in their autonomous ways of creating new knowledge in our discipline. All of the new directions have venerable traditions - albeit often forgotten - in history of psychology. These are not specifically covered in the discussions in this Issue, but need to be kept in mind when making sense of the directions offered.

First of the three innovations is the suggestion to return psychology as science to its original focus - that of complex psychological processes within every individual person. That kind of person-centered approach has emerged in the past fifty years and acquires particular rigor in the movement for idiographic science. What this means is a revolutionary move from evidence-based to experience-based (Baumann 2010) science in psychology. "Evidence" has habitually been seen as "big data" amassed by almost automatic data collection routines. This may fit demographic science or maybe some questions in sociology, but not psychology. Psychology's evidence is that of an experiencing - living, loving, frustrated, and happy - individual person in all of her or his complexity. Idiographic science adds to it the general proof of non-ergodicity of the psychological phenomena (Molenaar et al. 2002)—which renders the inference 
from sample-based data to individual persons-based application impossible on theoretical grounds.

Secondly - and following Zagaria et al. (2020) general suggestions on evolutionary psychology - the commentators arrive at the suggestion of advancement of general developmental science perspective beyond the traditions of evolutionary psychology along the lines of the genetic logic of James Mark Baldwin.

Finally, different suggestions converge on the building interdisciplinary synthesis between psychology and semiotics in the domain of cultural psychology. I am particularly pleased to see that direction emerging here in ways that go beyond the easy and trivial uses of the word "culture" that has hindered the development of the field in the pat three decades. The commentators here are coming close to the call for theoretical precision (Valsiner 2018) in psychology as a whole. For psychology to become a real science - among its peers of chemistry and biology - it needs to move from its dominance on inductive inference to that of abductive discovery of how psychological worlds are organized.

Research Involving Human and Animal Rights Theoretical paper, no use of human or animal participants.

\section{References}

Baucal, A., \& Krstic, K (2020). Searching for an integrative theoretical framework for psychology: Evolutionary psychology is needed but not sufficient. IPBS: Integrative Psychological \& Behavioral Science, 54, 3, xxx-yyy. https://doi.org/10.1007/s12124-020-09551-2

Baumann, S. L. (2010). The limitations of evidenced-based practice. Nursing Science Quarterly, 23(3), 226230.

Brinkmann, S. (2020). Moving on our feet: For a nomadic psychology. IPBS: Integrative Psychological \& Behavioral Science, 54, 3, xxx-yyy. https://doi.org/10.1007/s12124-020-09529-0.

Cairns, R. B., Elder, G., \& Costello, E. (Eds.). (1996). Developmental science. New York: Cambridge University Press.

Christensen, J. B. (2020). Is psychology an 'abysmal' science? IPBS: Integrative Psychological \& Behavioral Science, 54, 3, xxx-yyy. https://doi.org/10.1007/s12124-020-09540-5

DeLuca Picione, R. (2020). The semiotic paradigm in psychology: A mature weltanschauung for the definition of semiotic mind. IPBS: Integrative Psychological \& Behavioral Science, 54, 3, xxx-yyy. https://doi. org/10.1007/s12124-020-09555-y.

Di Nuovo, S. (2020). Searching for models for psychological science: A possible contribution of simulation. IPBS: Integrative Psychological \& Behavioral Science, 54, 3, xxx-yyy. https://doi.org/10.1007/s12124020-09539-y.

Gamsakhurdia, V. L. (2020). Systematic semiotic organization and anthropologization of the science of soultowards cultural psychology. IPBS: Integrative Psychological \& Behavioral Science, 54, 3, xxxyyy.https://doi.org/10.1007/s12124-020-09541-4

Gozli, D. (2020). Staying with questions and resisting quick answers. IPBS: Integrative Psychological \& Behavioral Science, 54, 3, xxx-yyy. https://doi.org/10.1007/s12124-020-09542-3.

Jensen, M. (2020). Wrong problem but right answer? . IPBS: Integrative Psychological \& Behavioral Science, 54, 3, xxx-yyy. https://doi.org/10.1007/s12124-020-09554-z.

Lundh, L-G. (2020). Persons and genes- is a gene-evolutionary psychology compatible with a person-oriented approach to psychological science? IPBS: Integrative Psychological \& Behavioral Science, 54, 3, xxxyyy. https://doi.org/10.1007/s12124-020-09548-x

Lux, V., \& Richter, J.-T. (Eds.). (2014). Kulturen der Epigenetik: Verebt, codiert, übertragen. Berlin: Walter de Gruyter. 
Marsico, G., \& Calandrini, A. R. (2020). Getting psychology back onto its feet: The developmental view of James mark Baldwin. IPBS: Integrative Psychological \& Behavioral Science, 54, 3, xxx-yyy. https://doi. org/10.1007/s12124-020-09535-2.

Marti, E. (2020). The need for epistemological vigilance. IPBS: Integrative Psychological \& Behavioral Science, 54, 3, xxx-yyy.https://doi.org/10.1007/s12124-020-09533-4

Märtsin, M. (2020). Psychology: A discipline in need of reflexive foundation. IPBS: Integrative Psychological \& Behavioral Science, 54, 3, xxx-yyy.https://doi.org/10.1007/s12124-020-09552-1

Mazur, L. (2020). Progress in psychological science: The importance of informed ignorance and curiositydriven questions. IPBS: Integrative Psychological \& Behavioral Science, 54, 3, xxx-yyy. https://doi. org/10.1007/s12124-020-09538-z.

Mironenko, I., \& Sorokin, P. (2020). Concerning paradigmatic status of psychological science: For a flexible and flowing psychology in the face of practical and theoretical challenges. IPBS: Integrative Psychological \& Behavioral Science, 54, 3, xxx-yyy.https://doi.org/10.1007/s12124-020-09530-7

Molenaar, P. (2004). A manifesto on psychology as idiographic science: Bringing the person Back into scientific psychology, this time forever. Measurement, 2(4), 201-218.

Molenaar, P., Huizinga, H. M., \& Nesselroade, J. R. (2002). The relationship between the structure of interindividual and intra-individual variability. In U. Staudinger \& U. Lindberger (Eds.), Understanding human development (pp. 339-360). Dordrecht: Klüwer.

Pinheiro, M. A. (2020). A Wittgensteinian comment on "psychology: A Giant with feet of clay"-A question from research on creativity. IPBS: Integrative Psychological \& Behavioral Science, 54, 3, xxx-yyy. https://doi.org/10.1007/s12124-020-09544-1.

Rudolph, L. (Ed.). (2013). Qualitative mathematics for the social sciences. London: Routledge.

Salvatore, S., Valsiner, J., Strout-Yagodzinsky, S., \& Clegg, J. (Eds.). (2009). YIS: Yearbook of idiographic science 2008, Vol (Vol. 1). Rome: Fireira Publishing.

Salvatore, S., Valsiner, J., Travers Simon, J., \& Gennaro, A. (Eds.). (2010a). YIS-2: Yearbook of idiographic science 2009. Roma: Fireira \& Luzio.

Salvatore, S., Valsiner, J., Travers Simon, J., \& Gennaro, A. (Eds.). (2010b). YIS-3: Yearbook of idiographic science 2010. Roma: Fireira \& Luzio.

Sato, T., Mori, N., \& Valsiner, J. (Eds.). (2016). Making of the future: The trajectory Equifinality approach in cultural psychology. Charlotte: Information Age Publishers.

Tateo, L. (2020). The Golem of psychology and the ecosystemic epistemology. . IPBS: Integrative Psychological \& Behavioral Science, 54, 3, xxx-yyy. https://doi.org/10.1007/s12124-020-09532-5.

Toomela, A. (2020). Psychology today: Still in denial, still outdated. IPBS: Integrative Psychological \& Behavioral Science, 54, 3, xxx-yyy. https://doi.org/10.1007/s12124-020-09534-3.

Toomela, A., \& Valsiner, J. (Eds.). (2010). Methodological thinking in psychology: 60 years gone astray? Charlotte, N.C: Information Age Publishers.

Tsuda, I. (2001). Toward an interpretation of dynamic neural activity in terms of chaotic dynamical systems. Behavioral and Brain Sciences, 24, 793-847.

Valsiner, J. (Ed.). (1986). The individual subject and scientific psychology. New York: Plenum.

Valsiner, J. (2010). A persistent innovator: James mark Baldwin reconsidered. Introduction to J. M. Baldwin, Genetic theory of reality (pp. xv-lix). New Brunswick: Transaction Publishers.

Valsiner, J. (2017). From methodology to methods in human psychology. New York: Springer.

Valsiner, J. (2018). Needed in psychology: Theoretical precision. Europe's Journal of Psychology, 14(1), 1-6. https://doi.org/10.5964/ejop.v14i1.602.

Valsiner, J. (2019). Culture \& Psychology: 25 constructive years. Culture and Psychology, 25(4), 429-469.

Valsiner, J., \& Sato, T. (2006). Historically structured sampling (HSS): How can psychology's methodology become tuned in to the reality of the historical nature of cultural psychology? In J. Straub, D. Weidemann, C. Kölbl, \& B. Zielke (Eds.), Pursuit of meaning (pp. 215-251). Bielefeld: Transcript.

Varzi, A. (1998). Basic problems of mereotopology. In N. Guarino (Ed.), Formal ontology in information science (pp. 29-38). Amsterdam: IOS Press.

Wu, A., \& Xu, S. (2020). One step further: Where to put the subjectivity of human mind in efforts of integrating psychology? IPBS: Integrative Psychological \& Behavioral Science, 54, 3, xxx-yyy. https://doi.org/10.1007/s12124-020-09549-w

Zagaria, A., Ando, A.,\& Zennaro, A. (2020). Psychology: A giant with feet of clay. IPBS: Integrative Psychological \& Behavioral Science, 54, 3, xxx-yyy. https://doi.org/10.1007/s12124-020-09524-5.

Publisher's Note Springer Nature remains neutral with regard to jurisdictional claims in published maps and institutional affiliations. 
Jaan Valsiner The Editor-in-Chief (since 2007) of the Integrative Psychological and Behavioral Science - Jaan Valsiner- is a cultural psychologist with a consistently developmental axiomatic base. Aside from the present Journal he is also the founding editor (1995) of the Sage journal, Culture \& Psychology. From 2013 to 2018 he was the Niels Bohr Professor of Cultural Psychology at Aalborg University, He has been awarded the Alexander von Humboldt Prize of 1995 in Germany, and the HansKilian-Preis of 2017, for his interdisciplinary work on human development. Previously while working in the United States he was a recipient of a Senior Fulbright Lecturing Award in Brazil 1995-1997. He has been a visiting professor in Brazil, Japan, Australia, Estonia. Germany, Italy, Luxembourg, United Kingdom, and the Netherlands. Since 2017 he is a Foreign Member of the Estonian Academy of Sciences. 